\title{
Characterization of cell surface components of Azospirillum brasilense Sp7 as antigenic determinants for strain-specific monoclonal antibodies
}

\author{
Michael Schloter, ${ }^{1}$ Sara Moens, ${ }^{2}$ Chris Croes, $^{2}$ Günther Reidel, ${ }^{3}$ \\ Murielle Esquenet, ${ }^{2}$ René De Mot, ${ }^{2}$ Anton Hartmann ${ }^{1}$ and Kris Michiels ${ }^{2}$
}

\author{
Author for correspondence: Michael Schloter. Tel: +49 89 31872304. Fax: + 498931873376 \\ e-mail: schlot@gsf.de
}

\author{
1 GSF - Forschungszentrum \\ für Umwelt und \\ Gesundheit, GmbH, Institut \\ für Bodenokologie, \\ Postfach, 85758 \\ Oberschleißheim, Germany \\ 2 F. A. Janssenslaboratorium \\ voor Genetica, Katholieke \\ Universiteit Leuven, \\ Willem de Croylaan 42, \\ B-3001 Heverlee, Belgium \\ 3 Nuklearmedizinische Klinik \\ und Poliklinik Rechts der \\ Isar der TU München, \\ Ismaninger Straße 22, \\ 85379 München, Germany
}

\begin{abstract}
Monoclonal antibodies (mAbs) with high specificity for Azospirillum brasilense Sp7, and which bind to different antigenic determinants, were characterized using Western blot techniques applied to one- and two-dimensional fingerprints of the outer-membrane components, and by immunogold labelling combined with transmission electron microscopy. One class of mAbs, which bound to $A$. brasilense $\mathrm{Sp7}$ and the closely related strain $\mathrm{Cd}$, recognized a $100 \mathrm{kDa}$ protein subunit of the polar flagellum. Two classes of strain-specific mAbs for A. brasilense Sp7 bound, respectively, to a 85 kDa outer-membrane protein and to polysaccharide.
\end{abstract}

Keywords: Azospirillum brasilense, cell surface, monoclonal antibodies, outer-membrane proteins, plant-microbe interactions

\section{INTRODUCTION}

Some bacteria of the genus Azospirillum have plantgrowth-promoting potential (Döbereiner \& Pedrosa, 1987; Okon, 1985). Important steps to establish this rhizocoenosis are the adsorption of bacteria to the root surface and the colonization of the root. It is known that different protein or carbohydrate components of the bacterial cell surface are involved in attachment to plant surfaces (Diaz et al., 1989; Vesper \& Bauer, 1986; Whatley et al., 1976). Lectin- and calcofluor-binding exocellular polysaccharides as well as surface proteins may be involved in the Azospirillum - root interaction (Del Gallo et al., 1989; Michiels et al., 1989). Some of the bacterial components involved in the interaction with root surfaces also play a role in self-aggregation and flocculation (Madi \& Henis, 1989; Michiels et al., 1991). Michiels et al. (1991) demonstrated that attachment of $A$. brasilense $\mathrm{Sp} 7$ to wheat roots occurs in two steps. The first step, a rapid and weak adsorption process, was abolished in a nonflagellated mutant, which was isolated by deletion mutagenesis of the $90 \mathrm{MDa}$ plasmid of $A$. brasilense Sp7. This plasmid was proposed as a rhizocoenotic plasmid (Croes $e t$ al., 1991). The second step, a firm anchoring of adsorbed bacteria, is probably mediated by surface polysaccharides

Abbreviations: mAb, monoclonal antibody; 1-D, 2-D, one-, twodimensional. (exopolysaccharides or lipopolysaccharides). The involvement of the polar flagellum in the Azospirillum-root adsorption was recently substantiated by Croes et al. (1993). Mutants with a deficient or altered surface polysaccharide structure, as shown by altered binding of calcofluor white to the mutant bacteria, were impaired in the anchoring process (Michiels et al., 1990).

To develop specific tools to study the molecular interaction of $A$. brasilense with roots, strain-specific monoclonal antibodies ( $\mathrm{mAbs}$ ) were isolated which bind to cell surface structures. Using the competition ELISA technique with mutants impaired in cell surface structures, $27 \mathrm{mAbs}$ were divided into three classes (Schloter et al., 1992). Class $1 \mathrm{mAbs}$ cross-reacted with many bacteria. The class $2 \mathrm{mAbs}$ reacted only with $A$. brasilense $\mathrm{Sp} 7$ and the closely related strain $\mathrm{Cd}$. The third class of $\mathrm{mAbs}$ bound specifically to $A$. brasilense Sp7. Using a competition ELISA, class $3 \mathrm{mAbs}$ were divided into the subclasses 3.1 and 3.2. (Schloter et al., 1992).

In this study, we used one-(1-D) and two-dimensional (2D) PAGE to separate outer-membrane and cell surface components of $A$. brasilense. The 2-D fingerprint was recently described by De Mot \& Vanderleyden (1989) as a strain-specific method to identify Azospirillum strains. The cell surface components to which the different types of $\mathrm{mAbs}$ bind were subsequently identified by Western 
blot analysis. The cellular localization of the antigenic determinants was further investigated by transmission electron microscopy of immunogold-labelled $A$. brasilense Sp7 cells.

\section{METHODS}

Bacterial strains and growth conditions. A. brasilense $\mathrm{Sp} 7$ was obtained from the German Collection of Microorganisms (DSM), Braunschweig, Germany. The mutant A. brasilense Sp7 p90D084, which is non-motile and lacks the polar flagellum, has been described recently (Croes et al., 1991, 1993). The bacteria were grown in Luria broth (LB) medium or 3\% trypticase soy broth at $33^{\circ} \mathrm{C}$ until early stationary phase.

Monoclonal antibodies. mAb-producing hybridoma cell lines were obtained by fusion of the mveloma cell line X63-Ag8.653 with B-lymphocytes of 1-4-month-old mice, which had been stimulated 1-5 times by immunization with live cells of $A$. brasilense Sp7 (Galfre \& Milstein, 1981). mAbs with high specificity for $A$. brasilense $\mathrm{Sp} 7$ were purified by hydroxylapatite column chromatography (Stanker et al., 1983). The present experiments are carried out with one $\mathrm{mAb}$ from each class: Mic 2-4.2 (class 2), Mic 4-1.2 (class 3.1) and Mic 3-8.1 (class 3.2).

Isolation of $\boldsymbol{A}$. brasilense polar and lateral flagella. We adopted the procedure described by De Pamphilis \& Adler (1971) with some modifications. Portions $(1 \mathrm{ml})$ of a fresh $A$. brasilense culture were spread on fifty $10 \mathrm{~cm} \times 10 \mathrm{~cm}$ square Petri dishes containing LB solidified with $1.5 \%(\mathrm{w} / \mathrm{v})$ agar. After $48 \mathrm{~h}$ incubation at $30^{\circ} \mathrm{C}$ in a humid atmosphere, cells were collected in $5 \mathrm{ml} 10 \mathrm{mM}$ Tris $/ \mathrm{HCl}(\mathrm{pH} \mathrm{8.0)}$ per plate. The bacteria were pelleted by centrifugation $\left(4 \times 10^{3} \mathrm{~g}, 15 \mathrm{~min}\right)$ and resuspended in $100 \mathrm{ml}$ of the same buffer. This suspension was mixed for $40 \mathrm{~s}$ at maximum speed in a Waring Blender mixer to break the flagella. The bacteria and cell debris were spun down from the mixed cell suspension for $15 \mathrm{~min}$ at $10^{4} \mathrm{~g}$. From the supernatant liquid, flagella were pelleted by ultracentrifugation for $90 \mathrm{~min}$ at $2 \times 10^{4} \mathrm{~g}$ and resuspended in $1 \mathrm{ml}$ of sterile water to obtain the crude flagellar suspension. For further purification and separation of polar and lateral flagella, $13.4 \mathrm{~g}$ dried $\mathrm{CsCl}$ was added and the volume of the suspension was adjusted to $30 \mathrm{ml}$ with $10 \mathrm{mM}$ Tris/ $\mathrm{HCl}$ ( $\mathrm{pH} \mathrm{8.0)}$. A density gradient was then established by spinning the samples for $60 \mathrm{~h}$ at $2 \times 10^{4} \mathrm{~g}$ in a Beckman SW28 rotor. Opalescent bands were carefully removed from the gradient with a Pasteur pipette, dialysed against water, lyophilized, and resuspended in $40 \mu \mathrm{l}$ water.

Isolation of outer-membrane proteins. Outer-membrane components were isolated by the method described by Bachhawat \& Gosh (1987) with some modifications. About $2 \times 10^{9}-4 \times 10^{9}$ stationary-phase cells grown in 3\% trypticase soy broth were washed twice with PBS $\left(\mathrm{gl}^{-1}: \mathrm{NaCL}, 8 ; \mathrm{KCl}, 0 \cdot 2 ; \mathrm{Na}_{2} \mathrm{HPO}_{4}\right.$, $1 \cdot 2 ; \mathrm{KH}_{2} \mathrm{PO}_{4}, 0 \cdot 2 ; \mathrm{pH} 7 \cdot 2$ ). The washed cells were sonicated for $6 \mathrm{~min}$ at $80 \mathrm{~W}$. The unbroken cells were removed by centrifugation for $10 \mathrm{~min}$ at $10^{3} \mathrm{~g}$. The supernatant was centrifuged at $6 \times 10^{4} \boldsymbol{g}$ for $30 \mathrm{~min}$ at $5^{\circ} \mathrm{C}$. The pellet, constituting the crude envelope fraction, was resuspended in $8 \mathrm{ml}$ of a $10 \mathrm{mM}$ Tris/ $\mathrm{HCl}$ buffer ( $\mathrm{pH} 8.0$ ) containing $0.5 \% \mathrm{~N}$-laurylsarcosine. After incubation for $30 \mathrm{~min}$ at $28^{\circ} \mathrm{C}$, the suspension was centrifuged at $5 \times 10^{4} \mathrm{~g}$ for $30 \mathrm{~min}$ at $5^{\circ} \mathrm{C}$. The pellet containing the outer-membrane components was resuspended in $100 \mu \mathrm{l} 10 \mathrm{mM}$ Tris $/ \mathrm{HCl}$ buffer ( $\mathrm{pH} \mathrm{8.0).} \mathrm{It} \mathrm{was} \mathrm{shown}$ by Bachhawat \& Gosh (1987) that this procedure yields an $A$. brasilense outer-membrane preparation which is not substantially contaminated with cytoplasmic or inner-membrane proteins (NADH oxidase and succinate dehydrogenase activity was measured). Compared with the use of sucrose gradient centrifugation to isolate outer (and inner) membranes from the crude envelope fraction, this method resulted in identical patterns for $A$. brasilense, but had the advantage of being much simpler to perform. Subsequently, proteins were isolated from the outer membranes by phenol extraction (De Mot \& Vanderleyden, 1989).

Lipopolysaccharide extraction. Outer membranes were prepared as described above using $1 \times 10^{8}$ stationary-phase cells (grown at $33^{\circ} \mathrm{C}$ in LB), but the final phenol extraction was omitted. The lipopolysaccharide fraction was obtained by proteinase $\mathrm{K}$ treatment $\left(25 \mathrm{mg} \mathrm{ml}^{-1}\right)$ at $37^{\circ} \mathrm{C}$ overnight.

One- and two-dimensional gel electrophoresis. 1-D gels were performed as SDS-polyacrylamide-pore-gradient-gels (10$22 \%$ ) with $4 \%$ stacking gels on a horizontal apparatus prepared according to Laemmli (1970) (1-D PAGE), using $0.375 \mathrm{M}$ Tris/ $\mathrm{HCl}(\mathrm{pH} 8 \cdot 8)$ as gel buffer. The dimensions of the gels were $30 \times 20 \times 0.02 \mathrm{~cm}$. The gels were transferred for Western blotting or stained with Coomassie brilliant blue R250 followed by silver nitrate staining (Heukeshoven \& Dernick, 1983).

2-D PAGE was carried out according to O'Farrell (1975) as described by De Mot \& Vanderleyden (1989). The gels were transferred for Western blotting or stained with Coomassie brilliant blue R250.

Western blotting. 1-D or 2-D gels were electroblotted on Immobilon-P membranes (Millipore). Immunodetection was performed in combination with a horseradish peroxidaseconjugated goat-anti-mouse secondary antiserum and with 4chloro-1-naphthol as a substrate to develop the blots (Harlow \& Lane, 1988).

Immunogold labelling and transmission electron microscopy (TEM). Bacteria were collected in PBS from a fresh LB plate and diluted to a density of $10^{8}$ cells $\mathrm{ml}^{-1}$. The cells were washed twice with PBS containing $1 \% \mathrm{BSA}$, incubated for $1 \mathrm{~h}$ with $100 \mu \mathrm{l}$ of the $\mathrm{mAb}$, washed three times with PBS $/ 0.02 \% \mathrm{BSA}$, incubated for $2 \mathrm{~h}$ with goat-anti-mouse gold conjugate $(5 \mathrm{~nm}$ gold particles), and finally washed three times with PBS $/ 0.02 \%$ BSA. Bacteria labelled with class $2 \mathrm{mAbs}$ were stained for $1 \mathrm{~min}$ with $1 \%$ phosphotungstic acid ( $\mathrm{pH} 7 \cdot 0)$ on Formvar- and carbon-coated copper grids for TEM.

Bacteria labelled with class $3 \mathrm{mAbs}$ were fixed for $10 \mathrm{~min}$ in $3 \%$ glutaraldehyde, washed once with PBS $/ 0.02 \% \mathrm{BSA}$ and embedded in LR white resin. Sections $(70 \mathrm{~nm})$ were cut with a microtome and were fixed on Formvar-coated copper grids for TEM.

\section{RESULTS}

\section{mAbs of class 2 bind specifically to the $A$. brasilense Sp7 polar flagellum}

A 2-D fingerprint of the cell surface proteins of $A$. brasilense Sp7 is shown in Fig. 1(a). Using a Western blot, the antigenic determinant of the class $2 \mathrm{mAbs}$, which cross-react with the closely related strains $A$. brasilense $\mathrm{Sp} 7$ and $A$. brasilense $\mathrm{Cd}$, was identified as a $100 \mathrm{kDa}$ protein with an isoelectric point of 3.5 (Fig. 1b). 2-D fingerprints of the cell surface proteins of the non-motile mutant $A$. brasilense Sp7 p90D084 revealed the absence in this mutant of the $100 \mathrm{kDa}$ protein recognized by $\mathrm{mAbs}$ of class 2 (not shown).

Using $\mathrm{CsCl}$ gradient centrifugation, two bands of different 

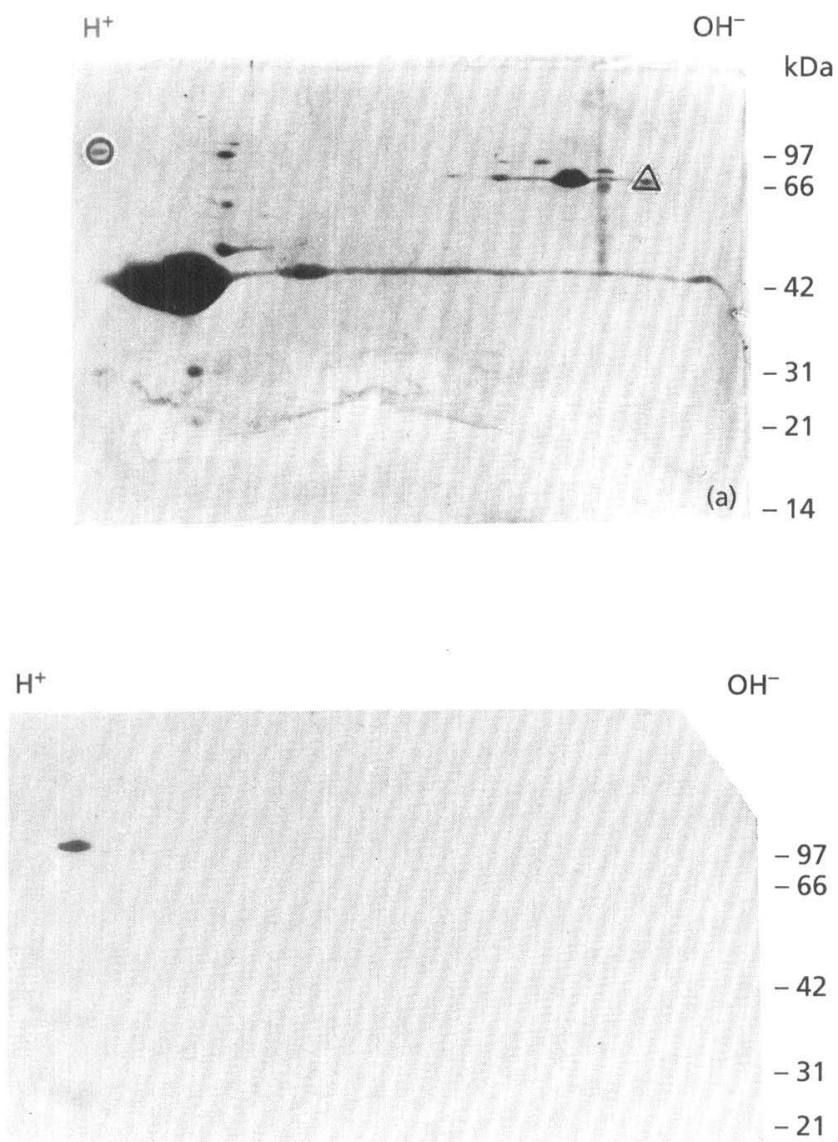

(b) -14

$\mathrm{H}^{+}$

$\mathrm{OH}^{-}$

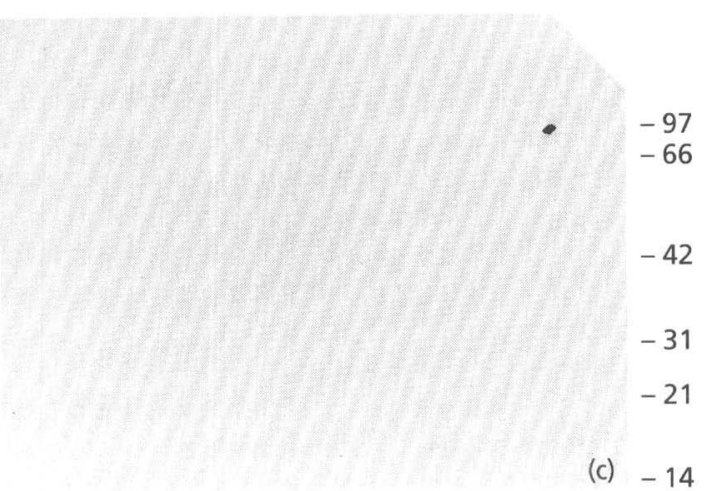

Fig. 1. Biochemical characterization of antigenic epitopes for the $A$. brasilense Sp7-specific mAbs. (a) 2-D fingerprint of the cell wall proteins of $A$. brasilense $\mathrm{Sp7}$. The gel was stained with Coomassie Blue. (b) Western blot of a 2-D fingerprint of the cell wall proteins of $A$. brasilense Sp7 with class 2 antibodies. For detection, 4-chloro-1-naphthol was used. The corresponding protein in Fig. 1(a) is marked with a circle. (c) Western blot of a 2-D fingerprint of the cell wall proteins of $A$. brasilense Sp7 with class 3.2 antibodies. For detection, 4-chloro-1-naphthol was used. The corresponding protein in Fig. 1(a) is marked with a triangle. A pH range from $3.5\left(\mathrm{H}^{+}\right)$to $10\left(\mathrm{OH}^{-}\right)$was used for the isoelectric focusing. The estimated molecular masses of the standard proteins are shown. (a)

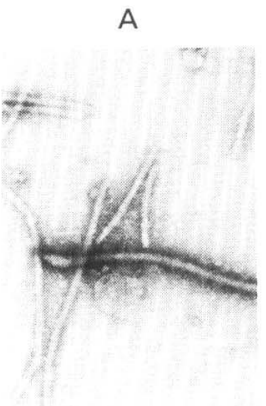

(b)

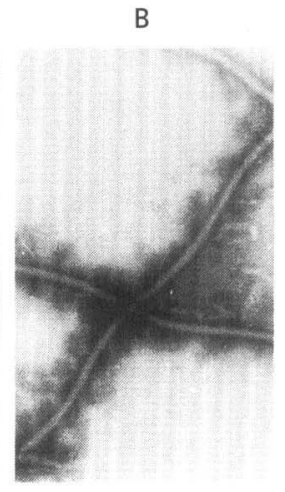

(c)

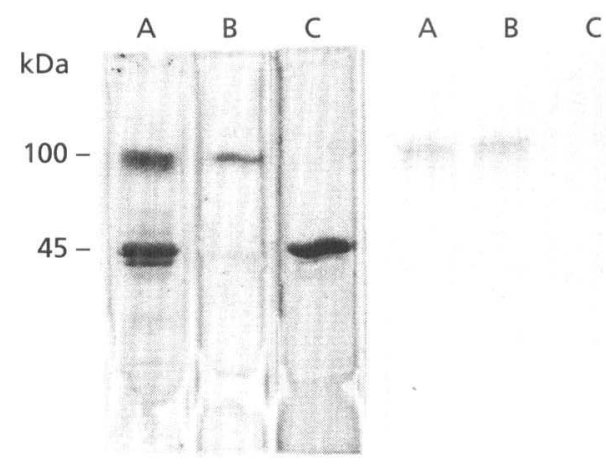

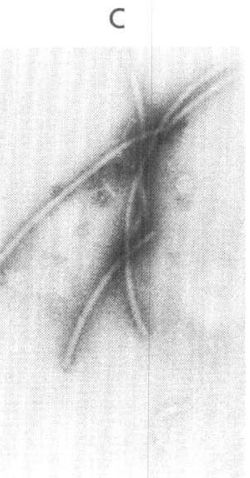

2. Analysis of flagellar preparations by TEM (a), SDS-PAGE (b) and Western blotting with class 2 mAbs (c). A, Crude flagellar preparation before $\mathrm{CsCl}$ fractionation, containing both types of flagella; $\mathrm{B}, \mathrm{CsCl}$ gradient lower band, containing the thick polar flagella; $\mathrm{C}, \mathrm{CsCl}$ gradient upper band, containing the thin lateral flagella. Estimated molecular masses of the flagellins are given.

density were obtained from crude flagellar extracts. The crude extract and the two $\mathrm{CsCl}$ purified fractions were examined by TEM after negative staining, and by SDSPAGE to identify the protein composition. TEM revealed fragments from two types of flagella differing in diameter. The high density $\mathrm{CsCl}$ fraction contained only the thick flagella, whereas the low density fraction contained the thin flagella (Fig. 2a). It is known that $A$. brasilense has a single polar flagellum, and produces multiple lateral flagella only in semi-solid or solid media. The latter are thinner and differ in antigenic properties from the polar flagellum (Hall \& Krieg, 1983). Thus, by $\mathrm{CsCl}$ centrifugation, we obtained an efficient separation of both flagellum types. SDS-PAGE revealed that the polar flagella (i.e. the heavy $\mathrm{CsCl}$ fraction) consist mainly of a $100 \mathrm{kDa}$ protein, whereas in the lateral flagella, a $45 \mathrm{kDa}$ protein is predominant. These major proteins likely represent the flagellins of the respective flagellum types. Minor protein bands, like the $40 \mathrm{kDa}$ band in both preparations, may represent other components of the flagellar structure or may be derived from the cell surface (Fig. 2b). A Western blot was prepared from a flagellar preparation 

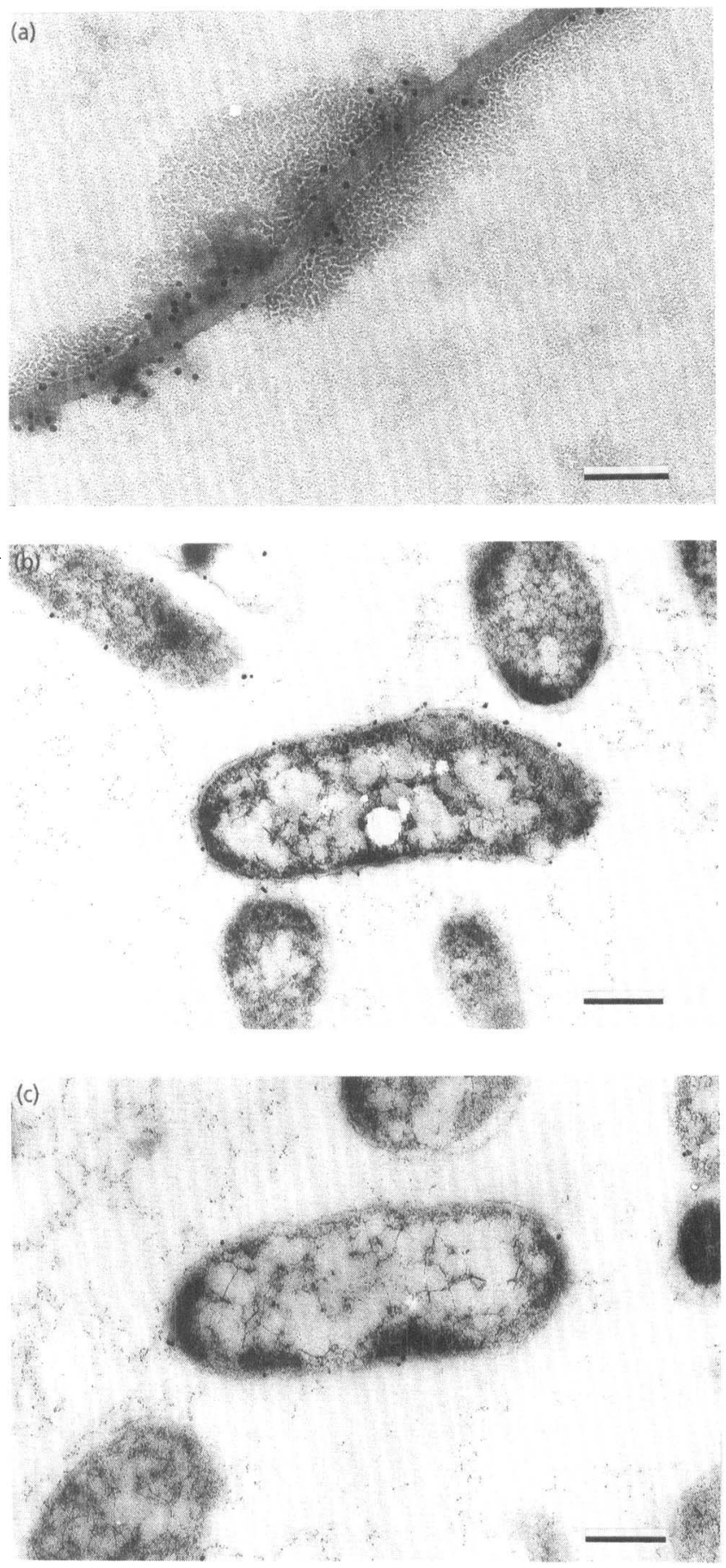

Fig. 3. Localization of the mAb epitopes by immunogold labelling of $A$. brasilense $\mathrm{Sp7}$ cells and TEM. (a) A polar flagellum of $A$. brasilense $\mathrm{Sp7}$ and immunogold labelling with class 2 mAbs. Bar, $0.5 \mu \mathrm{m}$. (b) A. brasilense Sp7 cells and immunogold labelling with class 3.1 mAbs. Bar, $5 \mu \mathrm{m}$. (c) $A$. brasilense Sp7 cells and immunogold labelling with class 3.2 mAbs. Bar, $5 \mu \mathrm{m}$.

after SDS-PAGE and developed with class $2 \mathrm{mAbs,}$ showing that these $\mathrm{mAbs}$ reacted with the $100 \mathrm{kDa}$ flagellin from the polar flagellum (Fig. 2c). The crude flagellar extracts of the non-motile mutant $A$. brasilense (a)

(b)
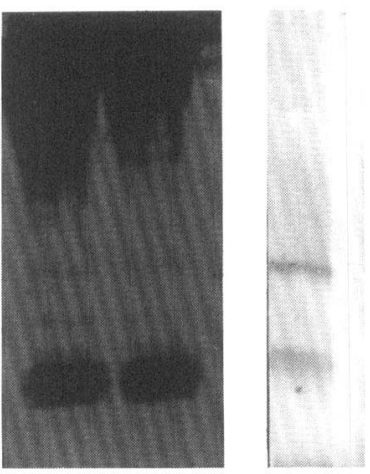

Fig. 4. Biochemical characterization of antigenic epitopes for the $A$. brasilense Sp7-specific class 3.1 mAbs. (a) 1-D SDS polyacrylamide gel of outer-membrane polysaccharides of $A$. brasilense Sp7. The gel was stained with silver. (b) Western blot of a 1-D SDS polyacrylamide gel of outer-membrane polysaccharides of $A$. brasilense Sp7 with class 3.1 mAbs. For detection, 4-chloro-1-naphthol was used.

Sp7 p90D084 did not yield any $\mathrm{CsCl}$ bands and did not contain the $45 \mathrm{kDa}$ and $100 \mathrm{kDa}$ flagellins (data not shown).

Binding of class $2 \mathrm{mAbs}$ to the polar flagellum was confirmed by immunogold labelling and TEM studies (Fig. 3a). No binding of class $2 \mathrm{mAbs}$ to the lateral flagella or the cell surface was observed. TEM studies of $A$. brasilense Sp7 p90D084 confirmed the results of lacking polar and lateral flagella (data not shown).

\section{mAbs of class 3.1 bind specifically to lipopolysaccharides of $A$. brasilense $5 p 7$}

mAbs, which belong to the $A$. brasilense Sp7-specific class 3.1, gave no Western blot signal on a 2-D fingerprint of the outer-membrane proteins. $A$. brasilense mutants altered in calcofluor white binding did not react with mAbs of class 3.1 (Schloter et al., 1992), suggesting that these $\mathrm{mAbs}$ bind to a cell surface polysaccharide. A lipopolysaccharide extract of $A$. brasilense $\mathrm{Sp} 7$ was prepared and separated by SDS-PAGE, yielding a multiple band pattern upon silver staining (Fig. 4a). Since no bands were seen after the gel had been stained with Coomassie blue, all proteins had been destroyed by proteinase $\mathrm{K}$ treatment. A Western blot of this gel developed with $\mathrm{mAbs}$ of class 3.1 resulted in two bands (Fig. 4b).

The binding of class $3.1 \mathrm{mAbs}$ to cell surface components was confirmed by immunogold labelling and TEM (Fig. $3 \mathrm{~b}$ ). As expected for a lipopolysaccharide-specific antibody, the gold label was distributed over the entire cell surface.

\section{mAbs of class 3.2 bind specifically to a $85 \mathrm{kDa}$ outer- membrane protein of $A$. brasilense Sp7}

$\mathrm{mAbs}$, which belong to the $A$. brasilense Sp7-specific class 3.2 , gave a signal on a Western blot of a 2-D fingerprint 
of the outer-membrane proteins of $A$. brasilense $\mathrm{Sp} 7$ with a basic $85 \mathrm{kDa}$ protein (Fig. 1c).

Binding of class $3.2 \mathrm{mAbs}$ to the cell surface was confirmed by immunogold labelling and TEM studies (Fig. 3c). The antigenic determinant is found at the cell surface.

\section{DISCUSSION}

By the use of Western blotting of 1-D or 2-D fingerprints of outer-membrane components and by immunogold studies, we have identified mostly strain-specific immunoreactive outer-membrane components of $A$. brasilense Sp7.

Three lines of evidence enabled the identification of the filament protein of the polar flagellum as the antigenic determinant for class $2 \mathrm{mAbs}$. Firstly, $\mathrm{mAb}$ binding to a $100 \mathrm{kDa}$ protein on Western blots of a 2-D fingerprint of outer-membrane proteins. This protein was identified as the major constituent of a polar flagellum preparation by SDS-PAGE. Secondly, lack of $\mathrm{mAb}$ binding to the mutant $A$. brasilense Sp7 p90D084 in ELISA (Schloter $e t$ al., 1992). This mutant is non-flagellate (Croes $e t$ al., 1993) and lacks the $100 \mathrm{kDa}$ protein. Thirdly, $\mathrm{mAb}$ binding to the polar flagellum was shown by immunogold labelling. Since the mutant $A$. brasilense Sp7 p90D084 which has a deletion in the rhizocoenotic 90 MDa plasmid, and other non-flagellate mutants, are unable to adsorb to the plant root surface (Michiels et al., 1991; Croes $e$ t al., 1993), the $\mathrm{mAbs}$ specific for the flagellum could be used in blocking experiments to independently demonstrate the involvement of flagella in the bacteria-root interaction. There is also evidence from a plant-growth-stimulating Pseudomonas fuorescens strain that flagella are required for colonization of potato roots (De Weger et al., 1987).

While the mAbs directed against the flagella attached to the closely related strains $\mathrm{Sp} 7$ and $\mathrm{Cd}$, the $\mathrm{mAbs}$ which bind to lipopolysaccharides recognize $A$. brasilense $\mathrm{Sp} 7$ specifically (Schloter et al., 1992). Lipopolysaccharide binding was demonstrated by Western blotting of a lipopolysaccharide preparation and by immunogold studies. It is well known that different parts of the $\mathrm{O}$ polysaccharides of the Gram-negative bacterial cell surface are very immunogenic (Lüderitz et al., 1982). The variations in the outer core region and the $\mathrm{O}$ polysaccharide antigen give rise to specific serotypes. Recently, mAbs against a relatively low molecular mass lipopolysaccharide of Pseudomonas aeroginosa were characterized (Yokota et al., 1992). Azospirillum mutants altered in calcofluor white binding, self-aggregation and the anchoring process on wheat roots have been described (Michiels et al., 1990, 1991). These mutants also failed to bind class $3.1 \mathrm{mAbs}$ as demonstrated by ELISA techniques, suggesting that they have modified lipopolysaccharides (Schloter et al., 1992). It would be very interesting to test the ability of in vivo inhibition of the anchoring process by these $\mathrm{mAbs}$ to assess the role of lipopolysaccharides in this process.

The $85 \mathrm{kDa}$ outer-membrane protein was demonstrated to carry the antigenic determinant for class 3.2 strainspecific $\mathrm{mAbs}$ and its surface location was corroborated by immunogold TEM investigations. However, no information about its function is available, because we do not have a mutant which fails to bind the mAbs.

Levanony \& Bashan (1989) showed a surface localization of specific antigens both at the polar flagellum and the exopolysaccharide layer by immunogold-staining using a polyclonal antiserum. As a polyclonal serum is mixture of different antibodies, it can bind to different epitopes.

It is an open question whether the high variability of antigenic cell surface structures of Azospirillum is an indiction of their ecological importance in adaptation to different soil and rhizosphere environments. It is most remarkable that $A$. brasilense strains $\mathrm{Sp} 7$ and $\mathrm{Cd}$ can be distinguished by $\mathrm{mAbs}$ against lipopolysaccharide and against the $85 \mathrm{kDa}$ outer-membrane protein, since both strains are very closely related. Strain $\mathrm{Cd}$ was isolated from Cynodon dactylon roots in California after inoculation with strain Sp7 (Tarrand et al., 1978). Strains Sp7 and Cd showed only very slight or no difference in restriction fragment lerigth polymorphism, which usually allows a strain-specific identification (Fani et al., 1991; Gündisch $e t$ al., 1993). Moreover, protein fingerprinting by 2-D PAGE revealed only few differences in the total protein pattern of these strains (De Mot \& Vanderleyden, 1989).

\section{ACKNOWLEDGEMENTS}

This work was supported by grants from the Deutsche Forschungsgemeinschaft, and from the Fonds voor Geneeskundig Wetenschappelijk Onderzoek (FGWO 3.0093.89). K. Michiels is a senior research assistant and R. De Mot a research associate with the NFWO (Belgium). We appreciate the help of Mrs Becke, Institute of Pathologie, GSF, in preparing the TEM pictures. We also thank the electron microscopy laboratory of the Centre for Human Genetics of the Katholieke Universiteit Leuven for the use of their equipment, and in particular B. Vanderschueren for her assistance.

\section{REFERENCES}

Bachhawat, A. K. \& Ghosh, S. (1987). Isolation and characterization of the outer membrane proteins of Azospirillum brasilense. $J$ Gen Microbiol 133, 1751-1758.

Croes, C. L., van Bastelaere, E., De Clercq, E., Eyers, M., Vanderleyden, J. \& Michiels, K. (1991). Identification and mapping of loci involved in motility, adsorption to wheat roots, colony morphology, and growth in minimal medium on the Azospirillum brasilense Sp7 90-MDa plasmid. Plasmid 26, 83-93.

Croes, C. L., Moens, S., van Bastelaere, E., Vanderleyden, J. \& Michiels, K. W. (1993). The polar flagellum mediates Azospirillum brasilense adsorption to wheat roots. J Gen Microbiol 139, 2261-2269.

De Mot, R. \& Vanderleyden, J. (1989). Application of twodimensional protein analysis for strain fingerprinting and mutant analysis of Azospirillum species. Can J Microbiol 35, 960-967.

De Pamphilis, M. \& Adler, J. (1971). Fine structure and isolation of the hook-basal body complex of flagella from Escherichia coli and Bacillus subtilis. J Bacteriol 105, 384-395.

De Weger, L., Van der Vlugt, C., Wijfjes, A., Bakker, P., Schippers, 
B. \& Lugtenberg, B. (1987). Flagella of a plant-growth-stimulating Pseudomonas fluorescens strain are required for colonization of potato roots. J Bacteriol 169, 2769-2773.

Del Gallo, M., Negi, M. \& Neyra, C. (1989). Calcofluor- and lectinbinding exocellular polysaccharides of Azospirillum brasilense and Azospirillum lipoferum. J Bacteriol 171, 3504-3510.

Diaz, C., Melchers, L., Hooykaas, P., Lugtenberg, B. \& Kune, J. (1989). Root lectin as a determinant of host-plant specificity in Rhizobium-legume symbiosis. Nature 338, 579-581.

Dobbereiner, J. \& Pedrosa, F. (1987). Nitrogen-fixing Bacteria in Nonleguminous Crop Plants. Madison: Science Tech Publishers.

Fani, R., Bazzicalupo, M., Gallori, E., Giovanetti, L., Ventura, S. \& Polsinelli, M. (1991). Restriction fragment length polymorphism of Azospirillum strains. FEMS Microbiol Lett 83, 225-230.

Galfre, G. \& Milstein, C. (1981). Preparation of monoclonal antibodies: strategies and procedures. Methods Enzymol 73, 3-46.

Gundisch, C., Baur, M., Kirchhof, G., Bode, W. \& Hartmann, A. (1993). Characterization of Azospirillum strains by RFLP and pulsed field gel electrophoresis. Microb Release 2, 41-45.

Hall, P. \& Krieg, N. (1983). Swarming of Azospirillum brasilense on solid media. Can J Microbiol 29, 1592-1594.

Harlow, E. \& Lane, D. (1988). Antibodies: A Laboratory Manual. Cold Spring Harbor, NY: Cold Spring Harbor Laboratory.

Heukeshoven, J. \& Dernick, R. (1983). Horizontale SDSElektrophoreses in ultradünnen Gradientengelen zur Differenzierung von Urinproteinen. In Proceedings of the Electrophorese Forum '83, München, pp. 92-97. Edited by B. J. Radola. Berlin: De Gruyter.

Laemmli, U. K. (1970). Cleavage of structural proteins during the assembly of head of bacteriophage T4. Nature 227, 680-685.

Levanony, H. \& Bashan, Y. (1989). Localization of specific antigens of Azospirillum brasilense $\mathrm{Cd}$ in its exopolysaccharide by immunogold staining. Curr Microbiol 18, 145-149.

Luderitz, O., Freudenberg, M. A., Galanos, C., Lehmann, V., Rietschel, E. T. \& Shaw, D. H. (1982). Lipopolysaccharides of Gram-negative bacteria. Curr Top Membr Transp 17, 79-151.

Madi, L. \& Henis, Y. (1989). Aggregation in Azospirillum brasilense
Cd. Conditions and factors involved in cell-to-cell adhesion. Plant Soil 115, 89-98.

Michiels, K., Vanderleyden, J. \& Van Gool, A. (1989). Azospirillum - plant root associations: a review. Biol Fertil Soils 8, 356-368.

Michiels, K., Verreth, C. \& Vanderleyden, J. (1990). Azospirillum lipoferum and Azospirillum brasilense surface polysaccharide mutants that are affected in flocculation. $J$ Appl Bacteriol 69, 705-711.

Michiels, K., Croes, C. \& Vanderleyden, J. (1991). Two different modes of attachment of Azospirillum brasilense $\mathrm{Sp} 7$ to wheat roots. $J$ Gen Microbiol 137, 2241-2246.

O'Farrell, P. H. (1975). High resolution two dimensional electrophoresis of proteins. J Biol Chem 250, 4007-4021.

Okon, Y. (1985). Azospirillum as a potential inoculant for agriculture. Trends Biotechnol 3, 223-228.

Schloter, M., Bode, W. \& Hartmann, A. (1992). Characterization of monoclonal antibodies against cell surface structures of $A \geq 0$ spirillum brasilense $\mathrm{Sp} 7$ using ELISA techniques. Symbiosis 13, $37-42$.

Stanker, L., Vanderlaan, M. \& Juarez-Salinas, H. (1983). One-step purification of mouse-monoclonal-antibodies from ascites by hydroxylapatite chromatography. J Immunol Methods 6, 157-169.

Tarrand, J., Noel, R. \& Dbbereiner, J. (1978). A taxonomic study of the Spirillum lipoferum group, with description of a new genus, Azospirillum gen. nov. and two species, Azospirillum lipoferum (Beijerinck) comb. nov. and Azospirillum brasilense sp. nov. Can J Microbiol 24, 967-980.

Vesper, S. J. \& Bauer, D.W. (1986). Role of pili (fimbriae) in attachment of Bradyrbizobium japonicum to soybean roots. Appl Environ Microbiol 53, 1397-1405.

Whatley, M. H., Bodwin, J. S., Lippincott, B. B. \& Lippincott, J. A. (1976). Role of Agrobacterium cell envelope lipopolysaccharide in infection site attachment. Infect Immun 13, 1080-1083.

Yokota, S., Terashima, M., Chiba, J. \& Noguchi, H. (1992). Variable cross-reactivity of Pseudomonas aeruginosa lipopolysaccharide-corespecific monoclonal antibodies and its possible relationship with serotype. J Gen Microbiol 138, 289-296.

Received 7 June 1993; revised 1 November 1993; accepted 11 November 1993. 